\title{
Dekonstruktion af Placebo Effekten og fundet af Betydningsrespons
}

\author{
Daniel Moerman ${ }^{1} \&$ Wayne Jonas ${ }^{2}$ \\ oversat af Ann Ostenfeld-Rosenthal \& Helle Johannessen
}

\footnotetext{
${ }^{1}$ Behavioral Science Department, University of Michigan-Dearborn dmoerman@umd.umich.edu

${ }^{2}$ The Samueli Institute, Department of Family Medicine, Georgetown University, and Uniformed Services University of Health Sciences wjonas@siib.org
}

Moerman, D. \& Jonas, W. oversættelse Ostenfeld-Rosenthal, A. \& Johannessen, H.(2015) Dekonstruktion af Placebo Effekten og fundet af Betydningsrespons, Tidsskrift for Forskning i Sygdom og Samfund, nr. 23, 17-30

Deconstructing the Placebo Effect and Finding the Meaning Response We provide a new perspect ve with which to understand what for a half century has been known as the "placebo effect. "We argue that, as currently used, the concept includes much that has nothing to do with placebos, confusirig the most interesting and important aspects of the phenomenon. We propose a new way to understand those aspects of medical care, plus a broad range of additional human experiences, by focusing on the idea of »meaning," to which people, when they are sick, often respond. We review several of the many areas in medicine in which meaning affects illness or healing and introduce the idea of the "meaning response."We suggest that use of this formulation, rather than the fixation on inert placebos, will probably lead to far greater insight into how treatment works and perhaps to real improvements in human well-being.

Oprindeligt publiceret i Annals of Internal Medicine 2002, 136:471-476. 


\begin{abstract}
Vi tilvejebringer et nyt perspektiv til at forstå det, som $i$ et halvt århundrede har været kendt som "placebo-effekten."Vi hævder, at, som det bruges $i$ dag, indeholder begrebet meget, der intet har at gøre med placebo og sammenblander dermed de mest interessante og vigtige aspekter af fænomenet. Vi foreslår, at en ny måde at forstå disse aspekter af lagebehandling på, samt en bred vifte af menneskelige erfaringer, vil være at fokusere pa ideen om »betydning «, som folk, når de er syge, ofte reagerer på. Vi gennemgår flere af de mange områder i medicin, hvor betydning påvirker sygdom eller helbredelse og introducerer ideen om »betydningsrespons."Vi foreslår, at anvendelsen af denne formulering, snarere end fastholdelse af ideen om den uvirksomme placebo sandsynligvis vil føre til langt større indsigt $i$, hvordan behandling virker og måske til reelle forbedringer $i$ menneskeligt velbefindende.
\end{abstract}

["The cure for the headache] was a kind of leaf, which required to be accompanied by a charm, and if a person would repeat the charm at the same time that he used the cure,he would be made whole; but that without the charm the leaf would be of no avail."

Sokrates, ifølge Platon (1)

Der er en fornyet interesse for placebo og placebo effekten - i forhold til deres realitet, etik, deres plads i lægevidenskab eller ikke, både i og uden for klinikken og det akademiske miljø. Det amerikanske National Institutes of Health sponsorerede fornyligt en stor konference, "Science af the Placebo" (2). Mindst fem seriøse bøger om emnet (3-7), en digtsamling (8) og en roman (9) - hver med titlen Placebo Effekt - er blevet offentliggjort siden 1997. I de seneste 10 år har det amerikanske National Library of Medicine årligt registreret gennemsnitligt 3.972 videnskabelige artikler med søgeordene "placebo«, "placebos« eller "placebo effect, « med et lavpunkt på 3.362 artikler i 1992 og et højdepunkt på 4.814 i år 2000. I løbet af efteråret 2000 opstod en diskussion af effekten af nye »modstandsfri« svømmedragter, som kan give en lille fordel til olympiske svømmere i US News and World Report: "Svømmekontrollanterne mener ikke, at det er andet end placebo-effekt. Svømmere udmærker sig, fordi de tror, de har fået en lille fordel«(10). Et meget omtalt studie, som konkluderede, at placebo var virkningsløst (11) eller repræsenterede Troldmanden fra Oz (12), foranledigede en storm af kritik (13-26) og en vis støtte (27). Det foregår i aviserne $(28,29)$. Det er i luften. 
Det seneste alvorlige forsøg på at prøve logisk at definere begrebet placeboeffekt mislykkedes fuldstændig (30). I betragtning af de måder hvorpå folk har tilnærmet sig fænomenet på, synes dette ikke overraskende. Arthur K. Shapiro, $\mathrm{MD}$, som tilbragte meget af sin karriere som psykiater med at studere placeboeffekten, skrev for nylig:

"A placebo is a substance or procedure ... that is objectively without specific activity for the condition being treated... The placebo effect is the ... therapeutic effect produced by a placebo." (31)

Hvis vi erstatter ordet »placebo« $\mathrm{i}$ den anden sætning med sin definition fra den første, får vi: "The placebo effect is the therapeutic effect produced by [things] objectively without specific activity for the condition being treated." Det giver overhovedet ingen mening. Det er indlysende. Det, vi kan være helt sikre på, er, at placebo ikke forårsager placebo effekter. Placebo er inaktiv og forårsager ikke noget.

Desuden udvider folk ofte begrebet placebo-effekt til meget bredt at omfatte næsten alle tænkelige slags gavnlige biologiske, sociale eller menneskelig interaktioner, der ikke involverer noget lægemiddel kendt i farmakopéen. En mere snæver form for denne begrebsekspansion inkluderer at identificere »naturlige forløb « eller »regression mod gennemsnittet« (som kan observeres i randomiserede, kontrolleret forsøg) som en del af placebo effekten. Men "naturlige forløb" og "regression mod gennemsnittet" forekommer ikke kun i kontrolgruppen. Intet i teorien om regression mod gennemsnittet (31) antyder, at når folk er udvalgt, fordi de har markante forekomster (højt blodtryk eller kolesterol, for eksempel), er de immune over for regression, hvis de modtager aktiv behandling. Det er lige så sandsynligt (eller usandsynligt), at sådanne deltagere bevæger sig mod homøostase (ligevægt) som patienter i kontrolgruppen. Så regression mod gennemsnittet kan ikke meningsfuldt siges at være en »placebo-effekt.« Ernst og Resch (32) tog et vigtigt skridt i forsøget på at afklare denne situation ved at differentiere den »ægte« fra den »opfattede« placebo-effekt. Men »ægte placebo-effekt« har ikke rigtigt slået an som et levedygtigt koncept.

Begrebet om placeboeffekten er imidlertid blevet udvidet langt mere. Nogle tilskriver effekten af forskellige alternative behandlingsformer, såsom homøopati (33) eller kiropraktik (34), placebo-effekten. Andre har beskrevet undersøgelser, der viser de positive virkninger af forbedret kommunikation, som f.eks. Egberts (35), som »placebo respons uden placebo« (7). Det er ikke underligt, at det virker forvirrende. 


\section{Betydning og medicin}

Vi foreslår at tænke over disse forhold på en ny måde. En gruppe medicinstuderende blev bedt om at deltage i en undersøgelse af to nye lægemidler, det ene et beroligende, og det andet stimulerende (36). Hver elev fik en pakke, der indeholdt enten en eller to blå eller røde tabletter; tabletterne var inaktive. De studerendes svar på et spørgeskema viste, at 1) de røde tabletter fungerede som stimulanser, mens de blå fungerede beroligende og 2) to tabletter havde større effekt end en. De studerende responderede ikke på tabletternes inaktivitet. Endvidere kan disse reaktioner ikke let forklares med naturlige forløb, regression mod gennemsnittet, eller lægens entusiasme (formentlig var forskerne lige så begejstrede for de røde som for de blå). I stedet kan de forklares ved »betydning « i forsøget: 1) Rød betyder »op«", »varm«, »fare«, mens blå betyder »ned «, »kølig«, »stille« og 2) to betyder mere end en. Disse virkninger af farve (37-40) og antal $(41,42)$ er blevet gentaget i vid udstrækning.

I et britisk studie blev 835 kvinder, der regelmæssigt anvendte smertestillende medicin mod hovedpine tilfældigt fordelt i fire grupper (43). En gruppe fik aspirin mærket med et kendt varenavn (»et af de mest populære" smertestillende midler i UK, som havde været »bredt tilgængeligt i mange år og understøttet af omfattende reklame «). De andre grupper fik enten samme aspirin i en helt enkel unavngiven pakning, et placebo præparat mærket med samme kendte varenavn, eller et placebo præparat i en umærket pakning. I denne undersøgelse virkede den navngivne aspirin bedre end aspirin uden varenavn, som virkede bedre end placebo med det kendte varenavn, som virkede bedre end placebo uden varenavn. Af 435 hovedpiner rapporteret af de, som fik navngiven placebo, blev 64\% rapporteret som forbedret 1 time efter pille indtaget sammenlignet med kun $45 \%$ af de 410 hovedpiner rapporteret af de, der fik unavngiven placebo. Aspirin lindrer hovedpine, men det gør viden om, at pillerne, du tager, er »gode«, også.

I en undersøgelse af fordelene ved aerobic træning deltog to grupper i et 10-ugers træningsprogram. En gruppe fik at vide, at udøvelsen ville øge deres evne til at optage ilt, mens den anden gruppe fik at vide, at udøvelsen ville styrke optagelsen af ilt og deres psykologiske velbefindende. Begge grupper forbedrede deres evne til at optage ilt, men kun den anden gruppe fik forbedret psykisk velbefindende (i realiteten »selvværd «). Forskerne kaldte dette »stærk evidens . . . for at motion kan forbedre psykisk velvære via en stærk placebo effekt »(44).

I studiet om røde versus blå piller kan vi korrekt (omend ikke særligt hjælpsomt) klassificere svarene fra de studerende som "placebo effekt», fordi de rent 
faktisk har modtaget inaktive tabletter; det synes dog klart, at de ikke reagerede på pillerne, men på deres farver. I den anden undersøgelse forbedrede det kendte varemærke virkningen af både det inaktive og det aktive lægemiddel. Det synes ikke rimeligt at klassificere »varemærke-effekten« som en »placebo-effekt«, fordi placebo ikke nødvendigvis er involveret. Imidlertid kan det, at kalde konsekvenserne af autoritativ undervisning af aerobic udøvere for "placebo-effekt«, kun komme fra en person, der mener, at ord ikke påvirker verden, en person, der aldrig er blevet fortalt »Jeg elsker dig“, eller som aldrig har læst bedømmelserne af afviste fondsansøgninger. Det synes rimeligt at kalde alle disse effekter (undtagen naturligvis af aspirin og motion) "betydnings-respons", et udtryk som blandt andet søger at genkalde Dr. Herbert Bensons term »afslapnings-respons« (45). Selvom placebo tydeligvis ikke kan gøre noget selv, kan dens betydning ironisk nok.

Vi definerer betydningsrespons som den fysiologiske eller psykologiske virkning af betydning i forhold til kilden til eller behandling af sygdom; betydningsrespons fremkaldt af brug af uvirksom eller falsk behandling kan kaldes "placeboeffekt«, når de er ønskelige og »nocebo effekt« (46), når de er uønskede. Dette er tydeligvis en kompleks samling af termer, som det ville være en udfordring at udfolde (»ønskelig, «, »effekt«, »betydning«, »behandling«, »sygdom«) - en øvelse, der ikke kan udføres her. Bemærk, at denne definition udelukker flere elementer, der normalt er indeholdt i vores forståelse af placebo-effekt, såsom det naturlige forløb, regression mod gennemsnittet, forsker eller subjekt bias og fejl i måling eller rapportering. Bemærk også, at definitionen ikke er formuleret i form af »ikkespecifikke« virkninger. Selv om mange elementer af betydningsrespons eller placebovirkning kan synes ikke-specifikke, er de i princippet ofte meget specifikke, efter de er forstået.

\section{Betydning gennemsyrer medicinsk behandling}

For så vidt som en behandling er betydningsfuld, kan den påvirke patienter, og den kan påvirke resultatet af et forløb (47-49). De fleste elementer af behandling er betydningsfulde, selvom behandlerne ikke har til hensigt, at de skal være det. Lægens beklædning (den hvide kittel med stetoskop hængende ud af lommen) (50), opførsel (entusiastisk eller ej), stil (terapeutisk eller eksperimentel) og sprog (51) er alle betydningsfulde elementer og kan påvises at påvirke resultatet; vi hævder netop, at både diagnose (52) og prognose (53) kan være vigtige former for behandling. 
Man kan referere mange undersøgelser, der dokumenterer aspekter af den terapeutiske kvalitet ved lægens opførsel (54). I en undersøgelse reducerede et stærkt budskab om effekten af et lægemiddel (en inaktiv kapsel) patienternes rapportering af smerten af blokade i underkæben sammenlignet med smerter efter et svagt budskab. Patienter, der fik det svage budskab, rapporterede mindre smerte end en gruppe, der hverken fik placebo eller noget budskab (55). I en anden undersøgelse blev 200 patienter med symptomer, men ingen unormale fysiske tegn, randomiseret til en positiv eller en negativ konsultation. I et spørgeskema, udfyldt af patienterne 2 uger senere, gav 64\% af patienterne i den positive konsultations gruppe udtryk for, at de havde det bedre, mens kun 39\% af dem, der havde negative konsultationer syntes, at de havde bedre (56).

Selv om der er stærk evidens for sådan en »læge-effekt, « er der meget lidt, der tyder på, at »patient-effekt« er særlig vigtig. En del forskning i 1970'erne foretaget med henblik på at identificere "placebo reaktorer« gav kun usammenhængende og modstridende resultater (57-59).

\section{Betydning kan have væsentligt fysisk påvirkning}

Placebo smertelindring kan fremkalde produktionen af endogene opiater. Smertelindring fremkaldt med en indsprøjtning af saltvandsopløsning kan modvirkes med antagonisten til opioider, naloxon og forbedres med agonisten til opioider, proglumide (60). Ligeledes kan akupunktur smertelindring modvirkes med naloxon hos dyr (61) og mennesker ( 62). At sige, at en behandling, såsom akupunktur "ikke er bedre end placebo" betyder ikke, at den ikke udvirker noget.

\section{Betydning og kirurgi}

Det klassiske eksempel på betydningsfuld virkning af kirurgi kommer fra to studier med afsnøring af de interne brystarterier som en behandling for angina pectoris $(63,64)$. Patienter, der fik en fingeret operation, kom sig lige så godt - 80 \% af patienterne oplevede en væsentlig forbedring - som dem, der fik den egentlige behandling i forsøgene eller i vanlig praksis. Selvom undersøgelserne var små, blev denne type behandling ikke længere udført, efter at rapporterne blev offentliggjort. Bemærk at disse effektivitets mål (og dem, som blev rapporteret af forta- 
lerne for proceduren på det tidspunkt) er meget lig dem, der opnås ved moderne behandlinger som kranspulsåre bypass-operationer eller beta-blokkere.๑

Visse iagttagere har foreslået, at den gode effekt af transmyocardial laser revaskularisering, en procedure uden en klar mekanisme, kan forklares ved det, de kalder placebo-effekt (65), men vi kalder betydningsresponsen. Dette er en plausibel fortolkning af et nyligt forsøg, der viste dramatisk forbedring ved meget syge mennesker i begge deltagergrupper i et kontrolforsøg med transmyocardial laser revaskularisering (Leon MB, Baim DS, Moses JW, Laham RJ, Knopf W. A randomized blinded clinical trial comparing percutaneous laser myocardial revascularizarion [using Biosense LV Mapping) vs. placebo in patients with refractory coronaiy ischemia. Præsenteret på American Heart Association Scientific sessionen , 12-15 November 2000).

Kirurgi er særlig betydningsfuld: Kirurger er blandt eliten af læger; blodsudgydelse er uundgåeligt betydningsfuld i sig selv. Derudover har kirurgiske procedurer normalt uafviselige rationelle forklaringer, hvilket medicinsk behandling ofte ikke har. Logikken i artroskopisk kirurgi (»vi renser et led, der er kommet i uorden«) er langt mere fornuftsbetonet og forstålig (og endda effektiv [66]), især for folk i en kultur rig på maskiner og værktøj end logikken i non-steroide anti-inflammatoriske lægemidler (som »hæmmer produktionen af prostaglandiner, der er involveret i den inflammatoriske proces, « noget ingen nogensinde ville fortælle en patient"). Kirurgi fremkalder klart en gennemgribende betydnings respons i moderne medicinsk praksis (67-69). 


\section{Figure. Data from 83 studies of the use of cimetidine or ranitidine for duodenal ulcer disease.}

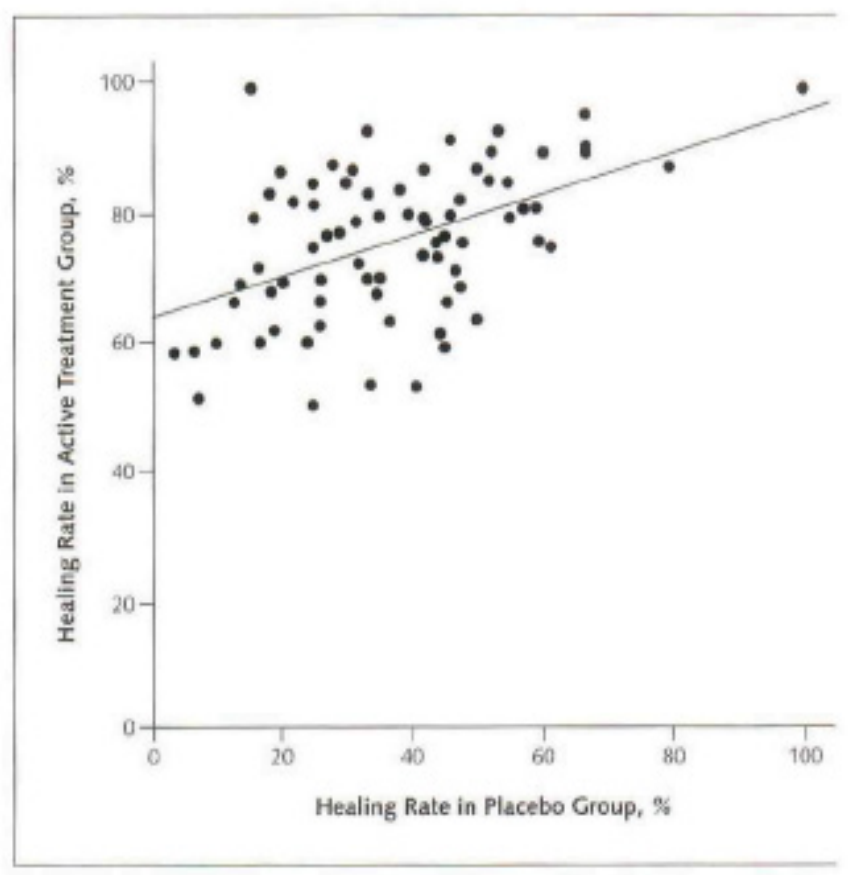

I alle tilfxelde blev mavesår og mavesårsheling diagnosticeret endoscopisk. De fleste studier varede 4 uger; et par stykker var lidt kortere eller længere. Sample sizes var på 12 til 210 deltagere (gennemsnit 58). Kvaliteten af disse studier var generelt god for den tid, hvor de blev gennemfort (hovedsageligt mellem 1976 og 1986), om end nok ikke fuldt tilfredsstillende efter nuværende standarder. Pointen af denne analyse er dog ikke, at afgøre hworvidt antisekretorisk medicin er virksom; det er den. Det væsentlige er forholdet mellem den farmakologiske og den betydningsrelaterede dimension af behandling. (En deltaljeret redegørelse for disse studier er tilgængelig andetsteds [42].)

\section{Betydning, kultur og medicin}

Antropologer forstår kultur som et komplekst væv af betydning, fyldige væv af forbundne opfattelser, metaforer og tegn. For så vidt som 1 ) betydning har biologisk konsekvens og 2) betydninger varierer imellem kulturer, kan vi forvente, at biologien vil være forskellig forskellige steder, ikke på grund af genetik, men på 
grund af disse sammenvævede ideer; vi kan forvente at se det, som Margaret Lock har kaldt »lokale biologier"(70 , 71); Lock har vist dramatisk tværkulturel variation i forekomsten og oplevelse af »overgangsalder« $(70,71)$. Desuden har Philips vist, at "Chinese Americans, but not whites, die significantly earlier than normal (1.3 to $4.9 \mathrm{y}$ ) if they have a combination of disease and birth year which Chinese astrology and medicine consider ill fated" (72). Blandt kinesiske amerikanere, hvis dødsfald blev tilskrevet lymfekræft $(n=3041)$, havde de, der var født $i$ »ord år « og dermed af kinesisk medicinsk teori blev anset for at være særligt modtagelige for sygdomme, der involverer klumper, knuder eller svulster - en gennemsnitlig alder ved dødstidspunkter på 59,7 år. I modsætning hertil havde kinesiske amerikanere, som var født i andre år, og som var døde af lymfekræft en gennemsnitsalder på 63,6 år - næsten 4 år mere. Lignende forskelle blev også fundet i forbindelse med forskellige andre alvorlige sygdomme. Sådanne forskelle sås ikke i store kohorter af »hvide«, som døde af lignende årsager i samme periode. Intensiteten af effekten viste sig at være korreleret med »styrken af engagement i traditionel kinesisk kultur«. Disse forskelle i levetid (op til 6\% eller 7\% forskel i levealder!) skyldes ikke, at de har kinesiske gener, men at de har kinesiske ideer, at de opfatter verden på en kinesiske måde. Virkningerne af betydning for sundhed og sygdom er ikke begrænset til placebo eller varemærker, men gennemsyrer livet.

En af os har vist, at der er variation i kontrolgruppers respons på uvirksom medicin i forskellige kulturer for de samme sundhedsproblemer (sår, forhøjet blodtryk og angst)(42). Figuren viser forholdet mellem helbredelse af kontrolgruppen og den aktive behandlingsgruppe for endoskopisk diagnosticeret sår på tolvfingertarmen behandlet med anti-sekretionsmedicin. Helbredelse af kontrolgruppe og aktiv behandlingsgruppe synes funktionelt relateret i disse undersøgelser. Korrelationen mellem kontrol og aktiv helbredelsesrate er 0,49; placebogruppens helbredelsesrate stiger, men det gør den aktive behandlingsgruppes rate også. Selv om den gennemsnitlige helbredelsesrate for kontrolgruppen i fem tyske undersøgelser var $62,4 \%$, var helbredelsesraten $16,7 \%$ i tre undersøgelser fra nabolandene Danmark og Holland. Det tal, som er nødvendigt for at behandle med fordel (NNTB), for at opnå helbredelse af mavesår, kan beregnes; for mavesårspatienter behandlet med placebo, er NNTB for de, der er tyske (ikke danske eller hollandske), 2 . 


\section{Konklusion}

Behandlere kan drage klinisk fordel ved at begrebsliggøre disse forhold som betydningsrespons frem for placebo-effekt. Placebo er inaktiv. Du kan ikke gøre noget med det. For mennesker er betydning alt det, placebo ikke er, overmåde levende og kraftfuld. Vi kender imidlertid ikke meget til denne kraft, selv om alle klinikere har oplevet den. En af grundene til, at vi er så uvidende, er, at ved at fokusere på placebo, er vi konstant nødt til at forholde os til de moralske og etiske implikationer ved at ordinere inaktive behandlinger $(73,74)$ eller lyve $(75)$ eller lignende. Det synes muligt at omgå hele spørgsmålet ved blot at undgå placebobehandlinger. Man kan imidlertid ikke undgå betydning, hvis man beskæftiger sig med mennesker. Selv de fjerneste objekter - planeten Venus, stjernerne i stjernebilledet Orion - er betydningsfulde for os, såvel som for andre (76).

Imidlertid er der stadig en kæmpe gåde: Selvfølgelig er betydningsrespons af stor værdi for de syge og lamme. Som eksempel kræver det en påfaldende lille indsats at fremkalde en betydningsrespons: (»De skal nok blive rask, hr. Smith«). Så hvorfor sker dette ikke hele tiden? Og hvorfor kan du ikke gøre det for dig selv? Psykolog Nicholas Humphrey har foreslået, at denne gåde kan have evolutionære rødder: Helbredelse har sine fordele, men også sine omkostninger (77). (At lindre smerter kan for eksempel tilskynde til for tidlig aktivitet, hvilket kan forværre en skade. Desuden er immunaktivitet metabolisk meget krævende for et skadet system.) Måske er det kun, når en ven, slægtning eller behandler viser en vis grad af social støtte (for eksempel ved at udføre et ritual), at den enkeltes indre økonomi tillader en at handle. Endvidere, eftersom vi har afklaret, rutiniseret og rationaliseret vores behandlinger og dermed sat vores lid til salicylater og glemt de mere betydningsfulde birketræer, piletræer og vintergrøn, hvorfra salicylaterne kom - og på den måde stort set fjernet Platons »trylleformular« - har vi forarmet betydningen af vores medicin i en grad, så den simpelthen ikke virker så godt, som den kunne længere. Interessante ideer som disse er umulige at opretholde, når vi diskuterer placebo; hvorimod de nemt dukker op, når vi taler om betydning.

\section{Referencer}

1. Jowett B. Dialogues of Plato. Chicago: Univ Chicago Pr; 1952.

2. "The Science of the Placebo: Toward an Interdisciplinary Research Agenda." National Institutes of Health, Bethesda, Maryland, 19-20 November 2000. Available at placebo. nih.gov. Accessed on 25 January 2002. 
3. Harrington A, ed. The Placebo Effect: An Interdisciplinary Exploration. Cam- bridge, MA: Harvard Univ Pr; 1997.

4. Shapiro AK, Shapiro E. The Powerful Placebo: From Ancient Priest to Modern Physician. Baltimore: Johns Hopkins Univ Pr; 1997.

5. Spiro HM. The Power of Hope: a Doctor's Perspective. New Haven: Yale Univ Pr; 1998.

6. Kirsch I, ed. How Expectancies Shape Experience. Washington, DC: American Psychological Association; 1999.

7. Brody H, Brody D. The Placebo Response: How You Can Release the Body's Inner Pharmacy for Better Health. New York: Cliff Street Books; 2000.

8. Beaumont JM. Placebo Effects: Poems. New York: W.W. Norton; 1997.

9. Russell G. Placebo Effect. New York: BBC Worldwide Americas; 1998.

10. Clark K, Milliken R. Today, it's "May the best swimsuit win." US News and World Report. 21 August 2000:55.

11. Hrobjartsson A, Gotzsche PC. Is the placebo powerless? An analysis of clinical trials comparing placebo with no treatment [Review]. N Engl J Med. 2001;344:1594-602. [PMID: 11372012]

12. Bailar JC 3rd. The powerful placebo and the Wizard of Oz. N Engl J Med. 2001;344:16302. [[PMID: 11372017]

13. Beldoch M. Is the placebo powerless? N Engl J Med. 2001;345:1278; dis- cussion 1278-9. [PMID: 11680460]

14. DiNubile MJ. Is the placebo powerless? N Engl J Med. 2001;345:1278; discussion 1278-9. [PMID: 11680459]

16. Kupers R. Is the placebo powerless? N Engl J Med. 2001;345:1278; discus- sion 1278-9. [PMID: 11680457]

17. Einarson TE, Hemels M, Stolk P. Is the placebo powerless? N Engl J Med. 2001;345:1277; discussion 1278-9. [PMID: 11680456]

18. Kaptchuk TJ. Is the placebo powerless? N Engl J Med. 2001;345:1277; discussion 1278-9. [PMID: 11680455]

19. Miller FG. Is the placebo powerless? N Engl J Med. 2001;345:1277; discus- sion 1278-9. [PMID: 11680454]

20. Lilford RJ, Braunholtz DA. Is the placebo powerless? N Engl J Med. 2001; 345:1277-8; discussion 1278-9. [PMID: 11680453]

21. Spiegel D, Kraemer H, Carlson RW. Is the placebo powerless? N Engl J Med. 2001;345:1276; discussion 1278-9. [PMID: 11680452]

22. Ader R. Much ado about nothing. Advances in Mind-Body Medicine. 2001; 17:293-95.

23. Brody H, Weismantel D. A challenge to core beliefs. Advances in Mind-Body Medicine 2001;17:296-8.

24. Greene PJ, Wayne PM, Kerr CE, Weiger WA, Jacobson E, Goldman P, et al. The powerful placebo: doubting the doubters. Advances in Mind-Body Medicine. 2001;17:298-307.

25. Kirsch I, Scorboria A. Apples, oranges, and placebos: heterogeneity in a meta-analysis of placebo effects. Advances in Mind-Body Medicine 2001;17:307-9.

26. Wickramasekera I. The placebo efficacy study: problems with the definition of the placebo and the mechanisms of placebo efficacy. Advances in Mind-Body Medicine. 2001;17:309-12.

27. McDonald CJ. Is the placebo powerless? N Engl J Med. 2001;345:1276-7; discussion 1278-9. [PMID: 11680451] 
28. Talbot M. The placebo prescription. New York Times Magazine. 9 January 2001: 34-9, 44, 58-60.

29. Rubin R. 'Eat one. You'1l feel better.' USA Today. 16 January 2001:D1.

30. Gøtzsche PC. Is there logic in the placebo? Lancet. 1994;344:925-6. [PMID: 7934350]

31. McDonald CJ, Mazzuca SA, McCabe GP Jr. How much of the placebo 'effect' is really statistical regression? Stat Med. 1983;2:417-27. [PMID: 6369471]

32. Ernst E, Resch KL. Concept of true and perceived placebo effects. BMJ. 1995;311:551-3. [PMID: 7663213]

33. Ernst E, Pittler MH. Efficacy of homeopathic arnica: a systematic review of placebocontrolled clinical trials. Arch Surg. 1998;133:1187-90. [PMID: 9820349]

34. Curtis P. Spinal manipulation: does it work? Occup Med. 1988;3:31-44. [PMID: 2963390]

35. Egbert LD, Battit GE, Welch CE, Bartlett MK. Reduction of postoperative pain by encouragement and instruction of patients. A study of doctor-patient rapport. $N$ Engl J Med. 1964;270:825-7.

36. Blackwell B, Bloomfield SS, Buncher CR. Demonstration to medical stu- dents of placebo responses and non-drug factors. Lancet. 1972;1:1279-82. [PMID: 4113531]

37. Schapira K, McClelland HA, Griffiths NR, Newell DJ. Study on the effects of tablet colour in the treatment of anxiety states. Br Med J. 1970;1:446-9. [PMID: 5420207]

38. Honzak R, Horackova E, Culik A. Our experience with the effect of placebo in some functional and psychosomatic disorders. Activa Nervosa Superior (Prague). 1971;13:190-1.

39. Cattaneo AD, Lucchilli PE, Filippucci G. Sedative effects of placebo treatment. Eur J Clin Pharmacol. 1970;3:43-5.

40. de Craen AJ, Roos PJ, Leonard de Vries A, Kleijnen J. Effect of colour of drugs: systematic review of perceived effect of drugs and of their effectiveness. BMJ. 1996;313:1624-6. [PMID: 8991013]

41. de Craen AJ, Moerman DE, Heisterkamp SH, Tytgat GN, Tijssen JG, Kleijnen J. Placebo effect in the treatment of duodenal ulcer. Br J Clin Pharmacol. 1999;48:853-60. [PMID: 10594490]

42. Moerman DE. Cultural variations in the placebo effect: ulcers, anxiety, and blood pressure. Med Anthropol Q. 2000;14:51-72. [PMID: 10812563]

43. Branthwaite A, Cooper P. Analgesic effects of branding in treatment of headaches. $\mathrm{Br}$ Med J (Clin Res Ed). 1981;282:1576-8. [PMID: 6786566]

44. Desharnais R, Jobin J, Co^te' C, Le'vesque L, Godin G. Aerobic exercise and the placebo effect: a controlled study. Psychosom Med. 1993;55:149-54. [PMID: 8475229]

45. Benson H, Klipper MZ. The Relaxation Response. New York: Wings Books; 1992.

46. Hahn RA. The nocebo phenomenon: concept, evidence, and implications for public health. Prev Med. 1997;26:607-11. [PMID: 9327466]

47. Levi-Strauss C. The Effectiveness of Symbols. Structural Anthropology. Garden City, NY: Anchor Books; 1967.

48. Moerman DE. Anthropology of symbolic healing. Current Anthropology. 1979;20:59-80.

49. Kirmayer LJ. Healing and the invention of metaphor: the effectiveness of symbols revisited. Cult Med Psychiatry. 1993;17:161-95. [PMID: 7693395]

50. Blumhagen DW. The doctor's white coat. The image of the physician in modern America. Ann Intern Med. 1979;91:111-6. [PMID: 88917] 
51. Uhlenhuth EH, Rickels K, Fisher S, Park LC, Lipman RS, Mock J. Drug, doctor's verbal attitude and clinic setting in the symptomatic response to phar- macotherapy. Psychopharmacologia. 1966;9:392-418. [PMID: 4872909]

52. Brody H, Waters DB. Diagnosis is treatment. J Fam Pract. 1980;10:445-9. [PMID: 7354290]

53. Christakis NA. Death Foretold: Prophecy and Prognosis in Medical Care. Chicago: Univ Chicago Pr; 1999.

54. Gracely RH. Charisma and the art of healing: can nonspecific factors be enough? In: Devor M, Rowbotham MC, Wiesenfeld-Hallin Z, eds. Proceedings of the 9th World Congress on Pain. Seattle: IASP Pr; 2000:1045-67.

55. Gryll SL, Katahn M. Situational factors contributing to the placebos effect. Psychopharmacology (Berl). 1978;57:253-61. [PMID: 97705]

56. Thomas KB. General practice consultations: is there any point in being positive? $\mathrm{Br} \mathrm{Med}$ J (Clin Res Ed). 1987;294:1200-2. [PMID: 3109581]

57. Moerman DE. Edible symbols: the effectiveness of placebos. Ann $N$ Y Acad Sci. 1981;364:256-68.

58. Fisher S. The placebo reactor: thesis, antithesis, synthesis, and hypothesis. Dis Nerv Syst. 1967;28:510-5. [PMID: 6048413]

59. Liberman RP. The elusive placebo reactor. In: Brill H, ed. Neuro-Psycho- Pharmacology: Proceedings of the Fifth International Congress of the Collegium Internationale Neuro-PsychoPharmacologicum. Amsterdam: Excerpta Medica Foundation. 1967:557-66.

60. Benedetti F, Amanzio M. The neurobiology of placebo analgesia: from en- dogenous opioids to cholecystokinin. Prog Neurobiol. 1997;52:109-25. [PMID: 9185235]

61. Pomeranz B, Chiu D. Naloxone blockade of acupuncture analgesia: endor- phin implicated. Life Sci. 1976;19:1757-62. [PMID: 187888]

62. Mayer DJ, Price DD, Rafii A. Antagonism of acupuncture analgesia in man by the narcotic antagonist naloxone. Brain Res. 1977;121:368-72. [PMID: 832169]

63. Cobb L, Thomas GI, Dillard DH, Merendino KA, Bruce RA. An evaluation of internalmammary artery ligation by a double blind technic. N Engl J Med. 1959;260:1115-8.

64. Dimond EG, Kittle CF, Crockett JE. Comparison of internal mammary ligation and sham operation for angina pectoris. Am J Cardiol. 1960;5:483-6.

65. Lange RA, Hillis LD. Transmyocardial laser revascularization [Editorial]. N Engl J Med. 1999;341:1075-6. [PMID: 10502599]

66. Moseley JB Jr, Wray NP, Kuykendall D, Willis K, Landon G. Arthroscopic treatment of osteoarthritis of the knee: a prospective, randomized, placebo-controlled trial. Results of a pilot study. Am J Sports Med. 1996;24:28-34. [PMID: 8638750]

67. Beecher HK. Surgery as placebo. A quantitative study of bias. JAMA. 1961; 176:1102-7.

68. Johnson AG. Surgery as a placebo. Lancet. 1994;344:1140-2. [PMID: 7934500] 69. Kaptchuk TJ, Goldman P, Stone DA, Stason WB. Do medical devices have enhanced placebo effects? J Clin Epidemiol. 2000;53:786-92. [PMID: 10942860]

70. Lock MM. Encounters with Aging: Mythologies of Menopause in Japan and North America. Berkeley: Univ California Pr; 1993.

71. Lock M. Menopause: lessons from anthropology. Psychosom Med. 1998;60: 410-9. [PMID: 9710286]

72. Phillips DP, Ruth TE, Wagner LM. Psychology and survival. Lancet. 1993; 342:1142-5. [PMID: 7901476] 
73. Macklin R. The ethical problems with sham surgery in clinical research. $N$ Engl J Med. 1999;341:992-6. [PMID: 10498498]

74. Reynolds T. The ethics of placebo-controlled trials. Ann Intern Med. 2000; 133:491. [PMID: 10975985]

75. Evans M. Justified deception? The single blind placebo in drug research. J Med Ethics. 2000;26:188-93. [PMID: 10860211]

76. McCleary TP. The Stars We Know. Crow Indian Astronomy and Lifeways. Prospect Heights, IL: Waveland Pr; 1997.

77. Humphrey N. Great expectations: The evolutionary psychology of faith- healing and the placebo response. In: Humphrey N, ed. The Mind Made Flesh: Essays from the Frontiers of Evolution and Psychology. Oxford: Oxford Univ Pr; 2002: Chapter 19. 